\title{
Microwave and autoclave usage in human teeth sterilization
}

\section{Uso de micro-ondas e autoclave na esterilização de dentes humanos}

\author{
Rafael Jordão Storino Vaz MONTEIRO' ${ }^{1}$ iD 0000-0002-9192-5345 \\ Bárbara Daphini Matos SILVA² iD 0000-0002-5160-3237 \\ Lorena Esteves SILVEIRA ${ }^{2}$ iD 0000-0002-3600-7103 \\ Maria Eugênia ALVAREZ-LEITE² ID 0000-0001-5065-8183 \\ Flavio Ricardo MANZI ${ }^{2}$ iD 0000-0001-9467-5137
}

Cláudia Valéria de Sousa Resende PENIDO² iD 0000-0001-7567-282X

\begin{abstract}
Objective: evaluate the sterilization of human teeth irradiated by microwaves. Methods: Sixty human third molars are divided into three groups ( $\mathrm{n}=20$ ): $\mathrm{G} 1$ without sterilization (negative control); $\mathrm{G} 2$ - autoclaving for 20 minutes $1 \mathrm{Kgf} / \mathrm{cm}^{2}$ at $120^{\circ} \mathrm{C}$ (positive control); $\mathrm{G} 3$ - sterilization in a microwave vessel containing $200 \mathrm{ml}$ of distilled water in a microwave irradiated at $650 \mathrm{~W}$ for 3 minutes. Results: No culture media of $\mathrm{G} 2$ and $\mathrm{G} 3$ presented contamination after autoclaving and microwave sterilization. Conclusion: Autoclave sterilization and microwave sterilization were effective decontamination methods under the experimental conditions tested.
\end{abstract}

Indexing terms: Deciduous tooth. Disinfection. Sterilization. Tooth.

\section{RESUMO}

Objetivos: avaliar a esterilização de dentes humanos através do uso da autoclave e da irradiação por micro-ondas. Métodos: Quarenta incisivos centrais superiores humanos foram distribuídos em três grupos: G1- sem esterilização (controle negativo); G2 - esterilização em autoclave, durante 20 minutos, $1 \mathrm{Kgf} \mathrm{cm}^{2}$, a $120^{\circ} \mathrm{C}$ (controle positivo); $\mathrm{G} 3$ - esterilização com micro-ondas em recipiente contendo $100 \mathrm{ml}$ de água destilada, irradiado a 900W em microondas durante 3 minutos. Resultados: Nenhum meio de cultura do G2 e G3 apresentou contaminação após esterilização em autoclave e microondas respectivamente. Conclusão: A esterilização em autoclave e a esterilização em micro-ondas foram métodos eficazes de descontaminação nas condições experimentais testadas.

Termos de indexação: Dente decíduo. Desinfecção. Esterilização. Dente.

\footnotetext{
$\nabla \nabla \nabla$
}

1 Universidade Federal de Minas Gerais, Faculdade de Odontologia, Departamento de Periodontia. Av. Antônio Carlos, 6627, Pampulha, 31270-901, Belo Horizonte, MG, Brasil. Correspondência para / Correspondence to: RJSV MONTEIRO. E-mail: <rafaelstorino1@ufmg.br>.

2 Pontifícia Universidade Católica de Minas Gerais, Faculdade de Odontologia. Belo Horizonte, MG, Brasil.

$\mathbf{v} \mathbf{v} \mathbf{v}$

Como citar estar artigo / How to cite this article

Monteiro RJSV, Silva BDM, Silveira LE, Alvarez-Leite ME, Manzi FR, Penido CVSR. Microwave and autoclave usage in human teeth sterilization. RGO, Rev Gaúch Odontol. 2018;66(4):317-320. http://dx.doi.org/10.1590/1981-863720180004000043437 


\section{INTRODUCTION}

Dental students need to perform preclinical technical procedures in the laboratory before practicing in patients. Some procedures can be taught by using manufactured teaching materials such as typodonts and artificial study models. However, there are situations in which there is no substitute for extracted human teeth such as in in vitro or in situ research studies, preparation of cavities and endodontic treatments. Teeth, as well as every organ of the human body, are a potential source of pathogenic microorganisms to human beings, requiring sterilization to prevent cross-infection to occur. This has led researchers to question the effectiveness of the sterilization methods and the possible damage to samples as a result of the method applied [1]

Studies have shown that the use of the autoclave, which uses moist heat under pressure, is effective in sterilizing teeth. The temperature required to achieve the sterilization process is approximately $121^{\circ} \mathrm{C}$, which may cause changes in the enamel and dentin, however, not destroying the organic components of the tooth structure. In order to the mentioned situation occur, it is necessary that the temperature reaches approximately $3000 \mathrm{C}$ [2]. Iodine-based solutions, sodium hypochlorite and formaldehyde may be effective but, also, may damage the tooth structure and take days to disinfect [3]. Sterilization with gamma irradiation is known to be the best technique to be applied, since it is lethal to all forms of microbiological life, not damaging the tooth structure. However, the high cost of the equipment, the complex processes involved and the extended sterilizing time limit the use of this method to some hospitals and companies [4]. Several studies report that microwave radiation inactivates many pathogenic microorganisms. This method has been indicated for disinfection and sterilization of dental prostheses, microbiology lab materials, medical and dental instruments and, recently, a study conducted on bovine teeth has also been reported on the literature [5-8].

This current research study has evaluated the sterilization of human teeth by using autoclave and microwave irradiation to promote disinfection and/or sterilization applying the above-mentioned methods.

\section{METHODS}

This current research study was approved by the Research Ethics Committee of the Pontifical Catholic
University of Minas Gerais (CAAE - 0067.0.213.000-11). Teeth used in this study were donated by the patients who were treated at the undergraduate and postgraduate clinics of the Pontifical Catholic University of Minas Gerais, after filling out the standard donation form from the Human Teeth Bank of the Pontifical Catholic University of Minas Gerais. Forty extracted human maxillary central incisor teeth, free from fractures and fissures, were selected through visual inspection. The teeth were cleaned in an ultrasonic tank and heated for 6 minutes, with $30 \mathrm{ml}$ of an enzymatic detergent. Subsequently, the teeth were sectioned longitudinally into two equal halves using a carborundum disc, under indirect irrigation with distilled water, to avoid overheating. The pulp tissue was removed. Each half of the tooth was conditioned in a previously sterilized glass bottle. Each bottle was labeled and numbered with information from the group to which the tooth belonged to, so that control was made, since one half belonged to the experimental group and the other half belonged to the positive control. The specimens were, then, distributed into three groups: $\mathrm{G} 1$ - with no sterilization (negative control); G2 - sterilization in autoclave (Sercon model AHMC5 - Mogi das Cruzes, São Paulo, Brazil), in a container with $100 \mathrm{ml}$ distilled water, wrapped in surgical grade paper, for 15 minutes, at $1700 \mathrm{~W}$ and temperature of $127^{\circ} \mathrm{C}$, with no drying cycle (positive control) [7]; G3 sterilization in microwave (Consul model CMY34ARHNA - Manaus, Amazonas, Brazil), in a container with $100 \mathrm{ml}$ distilled water, wrapped in surgical grade paper, at $900 \mathrm{~W}$ for 3 minutes. The choice of 900W was based on studies reporting that a voltage similar to this figure would promote effective disinfection [8-11].

The groups containing the specimens were sent to the Microbiology Laboratory of the Institute of Biological Sciences and Health of the Pontifical Catholic University of Minas Gerais in containers disinfected with $1 \%$ sodium hypochlorite, being processed in a laminar flow cabinet. Subsequently, they were immersed in tubes containing $10 \mathrm{~mL}$ of Brain Heart Infusion broth - BHI (Acme Manufacturers, Inc. Baltimore, Maryland) and stirred with sterile forceps for one minute. Then, they were transferred to another tube also containing Brain Heart Infusion broth. The purpose of this procedure was to create two culture media with microorganisms from the same specimen, so that one of them would be part of the group that was incubated in a bacteriological kiln at $37^{\circ} \mathrm{C}$, for 72 hours, under aerobic conditions; and the other would also be incubated in bacteriological kiln, during the same period 
and the same temperature, but under microaerophilic conditions. Therefore, at the end of the procedure, there was a total of 40 tubes from $\mathrm{G} 1$ (20 tubes from microwave and 20 tubes from autoclave), 40 tubes from G2 (20 tubes from autoclave under aerobic condition and 20 tubes from autoclave under microaerophilic condition) and 40 tubes from G3 (20 tubes from microwave under aerobic condition and 20 tubes from microwave under microaerophilic condition).

\section{RESULTS}

The culture media were read at 24, 48 and 72 hours following the procedure and the results have indicated the following: among the 40 culture media used for the negative control, which did not undergo any sterilization and/or decontamination process (G1), 10 of them did not present any type of contamination, since there was no turbidity after 72 hours. 40 tubes of each group that were analyzed after the testing processe, both in autoclave (G2 - positive control) and microwave (G3), did not show any contamination. Therefore, the conditions tested were considered decontaminated, being this the control positive.

\section{DISCUSSION}

The possibility of contamination from the use of extracted human teeth leads to the need of having sterilization or decontamination processes so that crossinfection can be controlled. The term disinfection and sterilization differs, as sterilization is the process by which all forms of microorganisms such as viruses, bacteria, fungi and spores are destroyed. Disinfection is the destruction of

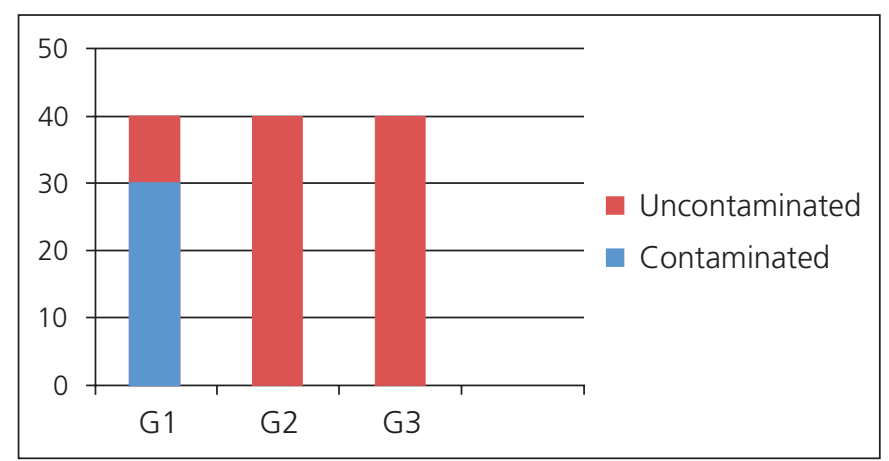

Figure 1. Comparison of the decontamination results. most, but not necessarily all, microorganisms, particularly the highly resistant ones. The mechanism by which microwave irradiation induces microorganism's death is not fully understood and, yet, needs to be clarified. Currently, it is not known if the use of microwave promotes sterilization or disinfection. It is believed that the sterilization or decontamination by microwave irradiation is caused by a combination of thermal and non-thermal conditions, since the electromagnetic field induced by the microwaves cause several effects on the chemistry of the biological molecules, leading to changes in the components of the cells, generating the sterilizing effect. The non-thermal effects differentiate the microwave action from the other methods that use only temperature as a method to eliminate microorganisms [8].

The present research study demonstrated that ten teeth from the control group did not show turbidity of the BHI culture medium after 72 hours. Therefore, the probable justification is that the cleaning process in ultrasonic tank, with 6-minute heating, and $30 \mathrm{ml}$ of an enzymatic detergent, was enough to carry out the disinfection of the same. These samples showed disinfection only with the ultrasonic cleaning process. Therefore, because the number was considerably low and prone to variations, it is necessary to associate the ultrasonic cleaning with another potentially safe method.

\section{CONCLUSION}

Autoclave sterilization at temperature of $127^{\circ} \mathrm{C}$, at $1700 \mathrm{~W}$, for 15 minutes, and microwave sterilization at $900 \mathrm{~W}$, for 3 minutes, were effective decontamination methods under the tested experimental conditions, since there was no growth of aerobic or microaerophilic microorganisms. The tested decontamination methods (autoclave and microwave) were effective considering the experimental conditions of this study.

\section{Collaborators}

RJSV MONTEIRO, conception and design, analysis and interpretation of data, review and approval of the final version of the article. BDM SILVA and LE SILVEIRA, design and drawing. MEA LEITE, analysis and interpretation of data, review and approval of the final version of the article. FR MANZI, statistical analysis and interpretation of results. CVSR PENIDO, conception and design, analysis and interpretation of data, review and approval of the final version of the article. 


\section{REFERENCES}

1. Dominici JT, Eleazer PD, Clark SJ, Staat RH, Scheetz JP. Disinfection/sterilization of extracted teeth for dental student use. J Dent Educ. 2001;65(11):1278-80.

2. Silva AR, Francci C, Rodrigues LE, Exposito Cl, Carvalho GF. Teeth sterilization: mechanical properties and enamel micromorphology by SEM. J Dent Res. 2000;79:565-5.

3. Hope CK, Griffiths DA, Prior DM. Finding an alternative to formalin for sterilization of extracted teeth for teaching purposes. J Dent Educ. 2013 Jan;77(1):68-71.

4. White JM, Marshall GW, Marshall SJ. Sterilization of teeth by Gamma Radiation. J Dent Res. 1994;73(9):1560-7. https:// doi.org/10.1177/00220345940730091201

5. Griffith D, Nacey J, Robinson R, Delahunt B. Microwave sterilization of polyethylene catheters for intermittent selfcatheterization. Aust N Z J Surg. 1993;63:203-4. https://doi. org/10.1111/j.1445-2197.1993.tb00519.x

6. Sanitá PV, Vergani CE, Giampaolo ET, Pavarina AC, Machado AL. Growth of Candida species on complete dentures: effect of microwave disinfection. Mycoses. 2008. 52(2):154-60. https://doi.org/10.1111/j.1439-0507.2008.01558.x

7. Cook JA, Pimenta LAF, Leonard R, Ritter AV, Lee JJ, NetteyMarbell A. Using extracted teeth for research: The effect of storage medium and sterilization on dentin bond strengths.
J Am Dent Assoc. 2007 Dec;138(12):1599-603. https://doi. org/10.14219/jada.archive.2007.0110

8. Viana PS, Machado AL, Giampaolo ET, Pavarina AC, Vergani CE. Disinfection of bovine enamel by microwave irradiation: effect on the surface microhardness and demineralization/ remineralization processes. Caries Res. 2010;44(4):349-57. https://doi.org/10.1159/000318528

9. Silva MM, Vergani CE, Giampaolo ET, Neppelembroek KH, Spolidorio DM, Machado AL. Effectiveness of microwave irradiation on the disinfection of complete dentures. Int J Prosthodont. 2006;19(3):288-93.

10. Mima EG, Pavarina AC, Neppelenbroek KH, Vergani CE, Spolidorio DM, Machado AL. Effect of different exposure times on microwave irradiation on the disinfection of a hard chairside reline resin. J Prosthodont. 2008;17(4):312-7. https://doi.org/10.1111/j.1532-849X.2007.00277.x

11. Neppelenbroek KH, Pavarina AC, Spolidorio DMP, Vergani CE, Mima EGO, Machado AL. Effectiveness of microwave sterilization on tree hard chairside reline resins. Int J Prosthodont. 2003;16(6):616-20.

Received on: 20/4/2018

Final version resubmitted on: 10/5/2018

Approved on: 15/6/2018 